\title{
First results of Central Asiatic Euchalcia DNA- studies: comparison of nucleotide sequence differences in COI between Euchalcia herrichi and Euchalcia gyulai (Lepidoptera: Noctuidae)
}

\author{
Stanislav K. Korb ${ }^{1}$ \\ 1 Russian Entomological Society, Nizhny Novgorod Division, P.O. Box 97 Nizhny Novgorod, 603009, \\ Russia \\ Corresponding author: Stanislav Korb (stanislavkorb@list.ru)
}

Academic editor: A. Matsyura | Received 11 February 2020 | Accepted 18 March 2020 | Published 9 April 2020

Citation: Korb SK (2020) First results of Central Asiatic Euchalcia DNA-studies: comparison of nucleotide sequence differences in COI between Euchalcia herrichi and Euchalcia gyulai (Lepidoptera: Noctuidae). Acta Biologica Sibirica 6: 1-4. https://doi.org/10.3897/abs.6.e52836

\begin{abstract}
We submitted first results of the DNA studies of the Central Asiatic owlet moths of the genus Euchalcia. Standard cytochrome C oxidase subunit I (COI) gene fragments were sequenced for DNA barcoding of six specimens belonging to Euchalcia herrichi and Euchalcia gyulai. We compared the received sequences between discussed species and with two European Euchalcia species (E. variabilis and E. consona). We found no variability within the COI sequences of the samples collected in the same locality (Alai Mts., Kyrgyzstan), whereas the difference in COI sequences between two populations (Ketmen Mts., Kazakhstan and Alai Mts., Kyrgyzstan) was 0.005 .
\end{abstract}

\section{Keywords}

Owlet moths, molecular taxonomy, COI, differences, Central Asia, Euchalcia.

\section{Introduction}

A total of three species of Euchalcia Hübner, [1821] were described during the last 15 years: E. olga Kravchenko, Muller, Fibiger, Mooser et L. Ronkay, 2006 from Israel, 
E. gyulai L. Ronkay, G. Ronkay et Behounek, 2008 from Tajikistan and Kyrgyzstan, and E. eos Saldaitis, Volynkin et Benedek, 2019 from Qinghai, China (Kravchenko et al. 2006; Ronkay et al. 2008; Saldaitis et al. 2019). Unfortunately, none of these descriptions have any DNA analysis.

In 2017-2019, the expeditions of the Russian Entomological Society (Nizhny Novgorod, Volgograd and Saratov Divisions) to Kyrgyzstan found a local population of recently described species, E. gyulai, in the Alai mountain range, Taldyk Pass (Korb et al. 2016). Moths were flying together with typical Central Asiatic species $E$. herrichi (Staudinger, 1861). Both species were used in DNA studies. Herein I report their results.

\section{Material and methods}

The following materials have been sequenced:

E. herrichi - two specimens collected together with E. gyulai in Kyrgyzstan, Alai Mts., Taldyk Pass, $3700 \mathrm{~m}\left(39.77233^{\circ} \mathrm{N}, 73.16711^{\circ} \mathrm{E}\right)$, using the same automatic autonomous light trap; 1 specimen collected near its type locality, in Kazakhstan, Ketmen Mts., Komirshi valley, $2400 \mathrm{~m}\left(43.05468^{\circ} \mathrm{N}, 79.69481^{\circ} \mathrm{E}\right)$.

E gyulai - three specimens collected together with E. herrichi in Kyrgyzstan, Alai Mts., Taldyk Pass, $3700 \mathrm{~m}$, using the same automatic autonomous light trap.

The material was sequenced by the BOLD project at the University of Guelph (Ratnasingham and Hebert 2007). All sequence operations were conducted using the MEGA v. 7.0 (Kumar et al. 2016) and BioEdit v. 7.2 .5 (Hall 1999).

As examples of European Euchalcia species, I used E. variabilis (Piller et Mitterpacher, 1783) and E. consona (Fabricius, 1787); their COI sequences were taken from Hausmann et al. (2011) and Mutanen et al. (2016).

\section{Results}

We did not discover any variability in three COI sequences of E. gyulai. The COI sequences of E. herrichi from Alai Mts. were also identical. The sequences of the latter species from Alai Mts. and from Ketmen Mts. had a small difference (p-distance 0.005). The differences between COI sequences of E. gyulai and E. herrichi from the same locality (Altai Mts.) are presented below (p-distance 0.139, Fig.1).

\section{Discussion}

The COI differences between European Euchalcia species are not as high as between high-mountainous Central Asiatic species. E. variabilis from Finland and E. consona from Germany had 48 different nucleotide pairs (p-distance was 0.078 ), while $E$. 
GHOTV940-18|Evchalcia gralai | GHOTV942-18|Euchalcia_herrichi

GHOTV940-18|Euchalcia gyalai | GHOTV942-18|Evchalcia_herrichi

GHOTV940-18|Buchalcia gralai | GHOTV942-18| Euchalcia_herrichi

GNOTV940-18|Euchalcia_gyalai | GWOTV942-18|Euchalcia_herrichi

GroTV940-18|Euchalcia_gralai | GHOTV942-18|Euchalcia_herrichi

GNOTV940-18|Euchalcia gyalai I GHOTV942-18|Euchalcia_herrichi

GNOTV940-18|Euchalcia_gyulai | GHOTV942-18|Euchalcia_herrichi

GHOTV940-18|Euchalcia_gralai | GNOTV942-18|Euchalcia_herrichi

GNOTV940-18|Buchalcia_gralai I GHOT942-18|Evchalcia_herrichi

GHOTV940-18| Evchalcia_gralai | GNOTV942-18|Evchalcia_herrichi GWOTV940-18|Euchalcia_gralai |
GWOTV942-18| Evchalcia_herrichi $\begin{array}{cccccc}20 & 20 & 30 & 40 & 50 & 60\end{array}$

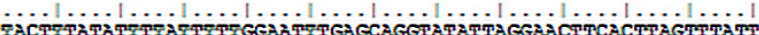

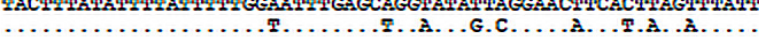
$\begin{array}{llllll}70 & 80 & 90 & 200 & 120 & 220\end{array}$

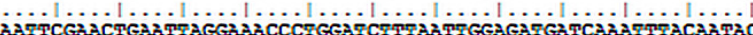

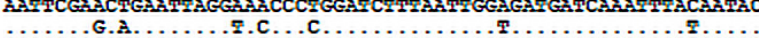
$\begin{array}{llllll}230 & 240 & 250 & 260 & 270 & 280\end{array}$

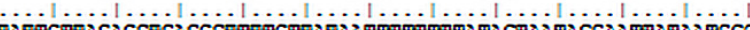

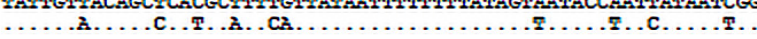
$\begin{array}{llllll}290 & 200 & 210 & 220 & 230 & 240\end{array}$ $\ldots|\ldots| \ldots|\ldots| \ldots|\ldots| \ldots|\ldots| \ldots|\ldots| \ldots|\ldots| \ldots \mid$

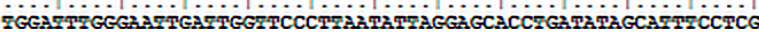

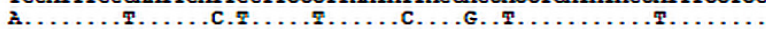
$\begin{array}{llllll}250 & 260 & 270 & 280 & 290 & 300\end{array}$

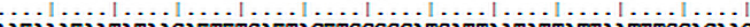
A

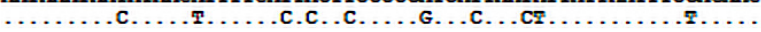
$\begin{array}{llllll}310 & 320 & 330 & 340 & 350 & 360\end{array}$ $\ldots|\ldots| \ldots|\ldots| \ldots|\ldots| \ldots|\ldots| \ldots|\ldots| \ldots|\ldots| \ldots|\ldots|$

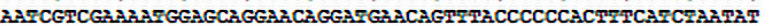

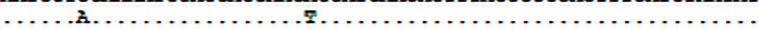

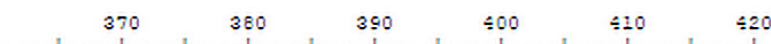

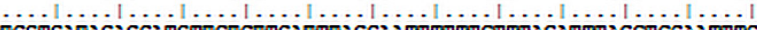

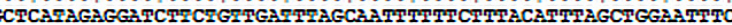

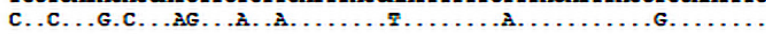
$\leqslant 30 \quad \div 40 \quad \div 50 \quad \div 60 \quad \div 70 \quad \div 80$

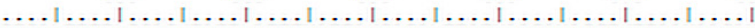

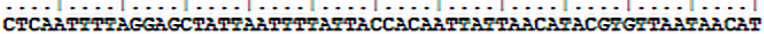

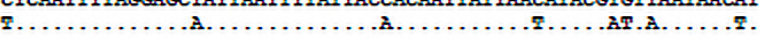
$\begin{array}{llllll}400 & 500 & 510 & 520 & 530 & 540\end{array}$

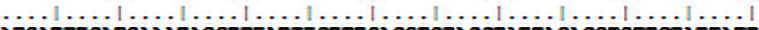

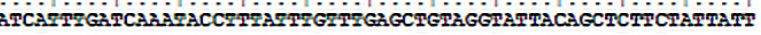
....$\ldots \ldots \ldots \ldots \ldots \ldots \ldots$. . . . . . . . . . . . . . . . . . . $\begin{array}{llllll}550 & 560 & 570 & 580 & 590 & 600\end{array}$

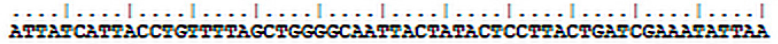

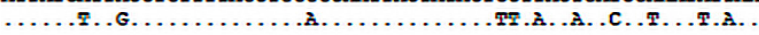
$610 \quad 620 \quad 630$

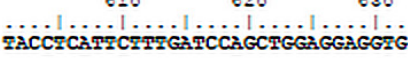
………..............

Figure 1. Alignment of the COI sequences of Euchalcia gyulai and E. herrichi

herrichi and E. gyulai from Altai Mts. had 88 different nucleotide pairs (p-distance was 0.139).

We registered that there was no variability within three samples of E. gyulai: all three received sequences were identical. The COI distances between two closely related species (E. herrichi and E. gyulai are very close habitually and inhabited the same biotopes) were relatively high: 0.139 for species collected from Altai Mts. and 0.135 between the samples of E. gyulai from Altai Mts. and E. herrichi from the Ketmen mountain ridge. The questions of this 'magic number' (what COI sequence p-distance is enough for the species delimination) is still open since the molecular methods were applied for taxonomy. Many scientists concluded, that there is no exact answer to this question. This should be specific for every group of organisms: in some genera the species can be separated by the difference in only 1-3 nucleotides (Burns et al. 2007); in some other groups, like discussed in this paper species from 
genus Euchalcia, the interspecific differences can widely vary and could reach the p-distance of 0.139 .

So, the 'universal' p-distance of 0.02, calculated by Huemer et al. (2014), is not an universal number in many cases. It must be calculated independently for every group of organisms basing on the sequencing statistics, comparative morphology, and ecology.

\section{References}

Burns JM, Janzen DH, Hajibabaei M, Hallwachs W, Hebert P (2007) DNA barcodes of closely related (but morphologically and ecologically distinct) species of skipper butterflies (Hesperiidae) can differ by only one to three nucleotides. Journal of the Lepidopterists' Society 61: 138-153.

Hall TA (1999) BioEdit: a user-friendly biological sequence alignment editor and analysis program for Windows 95/98/NT. Nucleic Acids Symposium Series 41: 95-98.

Hausmann A, Haszprunar G, Segerer AH, Speidel W, Behounek G, Hebert P (2011) Now DNA-barcoded: the butterflies and larger moths of Germany. Spixiana 34 (1): 47-58.

Huemer P, Mutanen M, Sefc K.M., Hebert P (2014) Testing DNA barcode performance in 1000 species of European Lepidoptera: large geographic distances have small genetic impacts. PLoS One 9 (12): e115775. https://doi.org/10.1371/journal.pone.0115774

Korb S, Matov A, Pliushch I, Klyuchko Z, Poltavsky A (2016) The Noctuoid moths of Kyrgyzstan. Moscow: KMK Scientific Press. 248 p.

Kravchenko VD, Muller GC, Fibiger M, Mooser J, Ronkay L (2006) A new Euchalcia Hübner, [1821] species from Israel (Lepidoptera: Noctuidae). SHILAP Revista de Lepidopterología 34 (136): 345-352.

Kumar S, Stecher G, Tamura K (2016) MEGA 7: molecular evolutionary genetics analysis version 7.0 for bigger datasets. Molecular Biology and Evolution 33 (7): 1870-1874. https://doi.org/10.1093/molbev/msw054

Mutanen M, Kivelä SM, Vos RA, Doorenweerd C, Ratnasingham S, Hausmann A, Huemer P, Dincă V, van Nieukerken EJ, Lopez-Vaamonde C, Vila R, Aarvik L, Decaëns T, Efetov KA, Hebert PD, Johnsen A, Karsholt O, Pentinsaari M, Rougerie R, Segerer A, Tarmann G, Zahiri R, Godfray HC (2016) Species-level para- and polyphyly in DNA barcode gene trees: strong operational bias in European Lepidoptera. Systematic Biology 65 (6): 1024-1040. https://doi.org/10.1093/sysbio/syw044

Ratnasingham S, Hebert P. 2007. BOLD: The Barcode of Life Data System (http://www. barcodinglife.org). Molecular Ecology Notes 7 (3): 355-364. https://doi.org/10.1111/ j.1471-8286.2007.01678.x

Ronkay L, Ronkay G, Behounek G (2008) The Witt Catalogue. A taxonomic atlas of the Eurasian and North African Noctuoidea. Plusiinae I. Budapest: Heterocera Press. 348 p. Saldaitis A, Volynkin AV, Benedek B (2019) A new Euchalcia Hübner, [1821] from Qinghai, China (Lepidoptera: Noctuidae). Zootaxa 4706 (3): 497-500. https://doi.org/10.11646/ zootaxa.4706.3.11 